\title{
THE ROLE OF GOVERNMENT POLICY IN DEVELOPING THE ISLAMIC MICROFINANCE INSTITUTIONS PERFORMANCE IN INDONESIA
}

\author{
${ }^{1}$ Tasya Aspiranti, ${ }^{2}$ A. Harits Nu'man, ${ }^{3}$ Yudha Dwi Nugraha, ${ }^{4}$ Ima Amaliah, ${ }^{5}$ Ade Yunita \\ Mafruhat \\ ${ }^{12345}$ Universitas Islam Bandung \\ Jalan Tamansari No. 24-26, Bandung Wetan, Bandung, 40116 \\ 1tasya@unisba.ac.id, ${ }^{2}$ haritsnuman.djaohari@gmail.com ${ }^{3}$ yudhadnoegraha@gmail.com, \\ 4amalia.razi@gmail.com 5ade.yunita.mafruhat@unisba.ac.id
}

\begin{abstract}
In building a successful Islamic Microfinance Institutions (IMFIs) performance, many factors must be considered based on a multi-element point of view. This study aims to build key factors affecting IMFIs performance using multi-perspective and multi-criteria methods. This study uses an analytic network process (ANP) to calculate the degree of influence given by the IMFIs performance criteria and factors. Primary and secondary data collection techniques are used to collect critical data for this research. The primary data are collected through questionnaires and interviews. A purposive sampling technique to collect primary data is used to the 26 local BPRS, 11 BMT including Java, Sumatra, and Sulawesi as Indonesia's three biggest islands. The study results find that internal and external management aspects are two main problems affecting IMFIs. Five main solutions to increase their financing are regulatory, management, institutions, competencies, and partnerships.
\end{abstract}

\section{Keywords: government policy; Islamic microfinance institutions}

\section{Introduction}

In recent decades, Islamic finance has emerged as one of the most important trends in finance. Muslims have a demand for financial products and services that comply with Islamic sharia principles. In Algeria and Jordan, the demand for such products and services varies in the range of 20 percent compared to 40 percent for Yemen and Syria. A similar trend is also found in Indonesia, Pakistan, Afghanistan, the Palestinian territories, and Muslim mainstream areas of India, Brunei, Sri Lanka, Cambodia, and the Philippines (Abbas \& Shirazi, 2015). Hassan (2015) argued that Islamic financial services would allow poorer Muslim households in financial inclusion and understand the problems and difficulties faced by economically poor Muslims.

Furthermore, Antonio (2008) argued that the provision of Islamic financial services needs to be considered an important tool for the poor's financial inclusion. 
Islamic microfinance is a sub-system of the Islamic financial system, and the role of microfinance in meeting development and social needs is indispensable. There is a greater demand for Sharia-based financial products and services with the Islamic finance industry's rapid development.

Microfinance is a financial institution that provides financial access to the poor who cannot reach conventional bank loans (Bashar \& Rashid, 2012). Microfinance is a non-profit sector due to the formal credit market's failure to finance the poor community market. Several studies related to microfinance (Armstrong et al., 2018; Bashar \& Rashid, 2012; Chikalipah, 2018; De Fontenay \& Wood, 2018; Hermes, 2014; Tavanti, 2013; Tchakoute Tchuigoua, 2017) converged on the formulation ideal for the welfare of the poor, reducing poverty, and income inequality. Islamic microfinance proves to have huge potentialities to fight against poverty financial and social exclusion and enlarge and enrich the basin of clients of financial institutions in developing countries with an Islamic cultural substratum (Segrado, 2005). A study by Karim et al. (2008) concluded that Islamic microfinance, which conforms to religious teachings, can combine Islamic social principles in caring for the less fortunate with the power of microfinance to provide access to finance for the poor.
Unlocking this potential could be the key to providing access to finance to the millions of poor Muslims who currently reject microfinance products that do not comply with Islamic law.

The proliferation of microfinance institutions (MFIs) in Indonesia has not yielded the desired impact, especially on financial inclusion and poverty alleviation. Kikkawa and Xing (2014) argued that the financing gap faced by the micro, small and medium-sized enterprises (MSMEs) still seems wide. In respect of poverty issue, numerous governmental programs have been established to increase access to financial services through microfinance programs such as People's Rural Bank (BPR - Bank Perkreditan Rakyat), People's Business Credit Programme (KUR - Kredit Usaha Rakyat), and Islamic People's Rural Bank (BPRS - Bank Perkreditan Rakyat Syariah). Several researchers (Karim et al., 2008; Hassan et al., 2013) expressed concern that microfinance providers' products are not universally compatible with poor Muslims' culture and belief systems, which hinders the depth of outreach in countries where the majority of Muslim, like Indonesia. Many Muslim communities are reluctant to participate in microfinance programs because religious values conflict with conventional MFI operations. In this regard, Islamic MFIs (IMFIs) may be a 
suitable alternative in countries where Muslims dominate. Thus, where Muslims are dominant, Indonesia can be the right place for Islamic MFIs to play a very important role in alleviating poverty through financial inclusion.

Previous research has been investigated factors that affect Muslim clients' participation in Baitul Maal wat Tamweel (BMT) (Maulana et al., 2018), current issues and challenges for Islamic microfinance (Abbas \& Shirazi, 2015), the relationship between Islamic microfinance and the socioeconomic welfare of women (Hassan \& Saleem, 2017), Islamic microfinance focus agenda for the economic enlistment of the poor minority community (Hassan, 2015), models and tools of Islamic agricultural finance for the rural poor (Obaidullah, 2015), co-operative nature of Islamic financial services providers (IFSPs) (Ahmad \& Ahmad, 2009), and significant factors influencing Islamic bank performance (Ulina \& Majid, 2020). However, a few studies have been carried out on the subject and experience in Islamic non-bank microfinance institution performance, specifically identifying and prioritizing key indicators of problems and solutions to assist policymakers in developing Islamic non-bank microfinance.

The present study aimed to identify and prioritize the index of the key indicators of problems and solutions using an ANP model to help policymakers develop Islamic non-bank microfinance among different provinces. This study uses analytical networking process estimation techniques to draw lessons from the problems faced by BMT and BPRS in particular so that good practice can be replicated elsewhere and bad practice, if any, may be avoided.

\section{Islamic Microfinance In Indonesia}

Islamic Micro Finance Institutions (IMFIs) in Indonesia are divided into three types, namely, Baitul Maal wat Tamweel (BMT), Islamic Rural Bank (BPRS - Bank Perkreditan Rakyat Syariah), and Islamic micro banking, which are offered by Islamic banks. In terms of clients, BMTs usually serve the lowest income group. Most of their clients are micro-entrepreneurs or petty traders in traditional markets, and sometimes farmers in agricultural areas. According to Rusydiana \& Devi (2013), BMT is an Islamic microfinance institution that combines the profit and non-profit motive (social). Baitul Maal aspects are developed, especially for members' welfare through ZISWA fundraising (zakat, infaq, charity, waqf, etc.) along with institutional strengthening. While BPRS serves lowerincome groups, those with more stable or established businesses might be classified as small entrepreneurs rather than microentrepreneurs. According to Law Number 
21, the Year 2008, Islamic rural banks' main characteristic is carrying out their activities without any service provider in the payment traffic. For Islamic micro-banking, they offer services to lower-upper and middleincome groups.

According to Obaidullah (2015), BMT is divided into two models: Baitul Maal and Baitul Tamweel. The former refers to a pool of various types of Islamic charity funds such as zakat-infaq-sadaqah and waqf funds. The latter reflects a pool of funds directed at for-profit financing using Shariacompliant modes such as micro-savings and investment deposits. BMT does not charge interest rates but usually deals with the principle of profit-loss sharing and practices Islamic moral values and group solidarity to increase loan repayments (Juwaini et al., 2010). Furthermore, most BMTs in Indonesia also practice regular meetings and counseling that reflect group solidarity. Although BMT is believed to be an effective way to assist micro-enterprises, Juwaini et al. (2010) argue that BMTs have developed without much support, systematic supervision, or regulation from the Indonesian government.

\section{The Development of Islamic Microfinance in Indonesia}

It is suggested that all types of BPRS finance could support IMFIs in Indonesia. Most of the financing provided to IMFIs is funded with murabahah contracts. In 2017 , the value of murabahah financing was 5.9 trillion rupiahs, increased by 850 billion rupiahs or 17 percent from what it was in 2016. The percentage of murabahah financing was dominated by 76 percent in 2017. A relatively small amount increased financing with the musharakah contract. In 2017, musharakah financing of BPRS composite was 776 billion rupiahs, increased by 2 billion rupiahs from the total financing of BPRS composite.

In addition to murabahah and musharakah financing, there is also financing under the mudharabah agreement. For more details of the development of these financing, see Figure 1.

Figure 1. Financing based on murabahah, musharakah, and mudharabah contracts in Indonesia Islamic community credit banks during the period of 2012 to July 2020

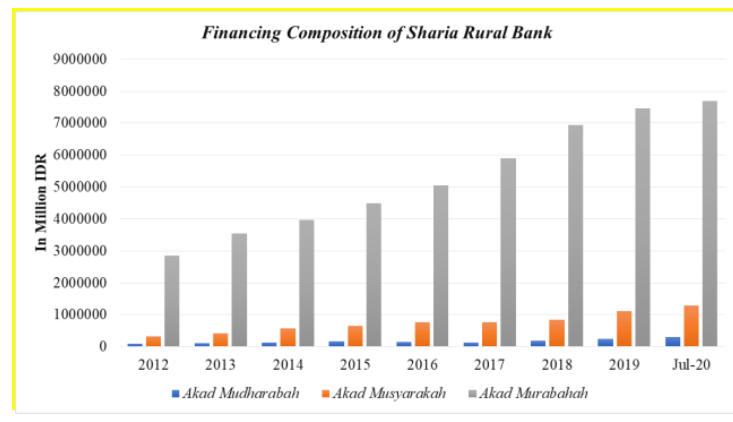

Source: Financial Services Authority (2019) Murabahah financing is still dominant compared to the other financing, which is closely related to the performance of INBMF in Indonesia. Based on the development of its assets, the performance 
of INBMF in Indonesia tends to increase, but it is still relatively small in absolute terms.

\section{Multi-Criteria Theory}

Decisions made in the Islamic microfinance sector can directly impact the living conditions and well-being of Muslim communities. The Islamic microfinance sector must consider a large number of factors, particularly in the process of resource allocation, policies, internal and external management. Therefore, using the multiple criteria decision-making (MCDM) method is very important for Islamic microfinance decision-makers to support their decisions.

ANP can be defined as a multicriteria theory, allowing decision-makers to compose decisions in a conceivable general manner. The representation of any decision problem with no concern about what comes first or next is possible using a network structure when the sources, cycles, and sinks are addressed (Machado et al., 2014). Applying ANP as MCDM can provide a more transparent and data-driven decision process while taking intangible aspects and decision-makers' preferences into account (Machado et al., 2014).

ANP, a generalized form of AHP, can be applied as an efficient tool in the cases where the interactions among the elements lead to the formation of a network structure being beneficial under different real-world conditions (Saaty \& Vargas, 2013). ANP approach is widely used for prioritization, performance evaluation, and other contexts (Feibert et al., 2016; Yellepeddi et al., 2006). It can detect feedback and interdependent associations among and between the components (Agarwal et al., 2006).

\section{Methods}

Analytical networking process (ANP) is used to explain the key factors affecting IMFIs performance. In particular, ANP calculates the level of influence exerted by the IMFIs performance criteria and factors and determines the relationship between the criteria and key factors. ANP is a generalized form of the widely used multicriteria decision-making technique of AHP (Saaty, 1980).

Compared to AHP, the ANP methodology makes it possible to consider all kinds of dependence and feedback in the decision problem. Thus, the ANP method is better to provide a flexible model to solve real-world situations than the AHP method (Sipahi \& Timor, 2010). Overall, ANP offers several advantages over other evaluation techniques such as data envelopment analysis (DEA), expert systems, goal programming, etc. (Sarkis \& Sundarraj, 2006). 
ANP represents a decision problem as a network of elements grouped into clusters. The characteristic of ANP enables to work with interdependent criteria and provides a much more accurate approach for modeling complex real environments. Compared to AHP, the ANP methodology makes it possible to consider all kinds of dependence and feedback in the decision problem. Thus, the ANP method is better to provide a flexible model to solve real-world situations than the AHP method (Sipahi \& Timor, 2010). Overall, ANP offers several advantages over other evaluation techniques such as data envelopment analysis (DEA), expert systems, goal programming, etc. (Sarkis \& Sundarraj, 2006).

\section{Data collection and sample}

Primary and secondary data collection techniques are used to collect the required data for this research. The primary data are collected through questionnaires and interviews. The secondary data is obtained by reviewing some documents, books related to the research, such as BPRS and BMT profiles throughout Indonesia, judging the aspects of potential BPRS, the rate of profit growth, and the development of BPRS establishment in Indonesia. A purposive sampling technique is used based on the locations that have access to the local BPRS, including on the islands of Java and Sumatra and part of the island of Sulawesi.
11 BMT and 26 BPRS in the three biggest Island of Indonesia are samples to represent Indonesia IMFIs as shown in Table 1.

Table 1. Samples of the research

\begin{tabular}{|c|l|c|c|}
\hline No & \multicolumn{1}{|c|}{ Province } & BMT & BPRS \\
\hline 1 & East Java & 2 & 5 \\
\hline 2 & Middle Java & 2 & 3 \\
\hline 3 & West Java & 2 & 2 \\
\hline 4 & Yogyakarta & 3 & 2 \\
\hline 5 & Aceh & 0 & 4 \\
\hline 6 & North Sumatera & 0 & 5 \\
\hline 7 & West Sumatera & 1 & 4 \\
\hline 8 & South Sulawesi & 1 & 3 \\
\hline \multicolumn{2}{|c|}{ Total } & 11 & 26 \\
\hline
\end{tabular}

Source: Primary Data (2019)

\section{Data analysis}

Data analysis was performed using ANP. ANP computes complex relationships between decision elements by replacing a hierarchical structure with a network structure (Saaty, 1999). ANP considers each issue as a network of criteria, sub-criteria, and alternatives. Compared to AHP, the ANP methodology makes it possible to consider all kinds of dependence and feedback in the decision problem. Thus, the ANP method is better to provide a flexible model to solve real-world situations than the AHP method (Sipahi \& Timor, 2010).

\section{Discussion}

Based on the results of the study, numerous problems and solutions are identified. In the context of problem 
identification, it was related to the policy to develop Islamic microfinance performance in Indonesia that can be viewed from external aspects that have indicators in the field of IMFIs regulation and partnership. Besides, problems can also be viewed from the internal IMFIs factors such as human resources and financial management, institutional, and human resources competencies.

In solution identification, they were presented in response to existing problems related to external aspects, namely from IMFIs regulations and partnerships. The solutions offered can also be seen from IMFIs internal factors such as human resource management, financial management, institutions, and human resource competence.

The key performance components of problems and solutions are processed using ANP to obtain a conducive and effective strategic formulation to build BPRS and IMFIs.

\section{Key Performance Index of Problems}

Based on the calculations and problems studied, it is known that the problems faced mostly come from the internal aspects of 62 percent and the external aspects of 38 percent. Overall, the problem cluster has a total value of 69.08 with a comparison of values, as shown in Figure 2.
Figure 2. Indicator of problematic aspects

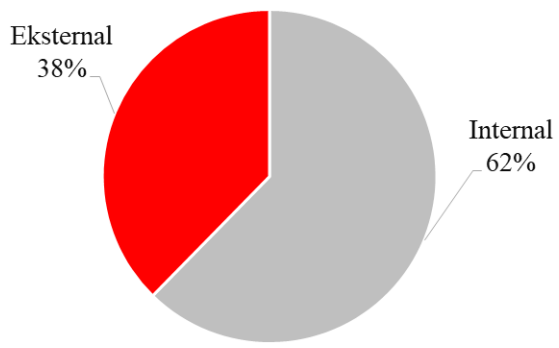

Source: Primary data (2019)

The indicators' assessment shows that the highest problem aspect is institutional, with 16.70 percent, followed by regulations at 16.59 percent, and management with 14.70 percent. Meanwhile, the competency aspect scored 11.70, and the partnership aspect scored 9.42 percent, as shown in Figure 3.

Figure 3. Indicators of problematic aspects Problematic Aspect Indicator

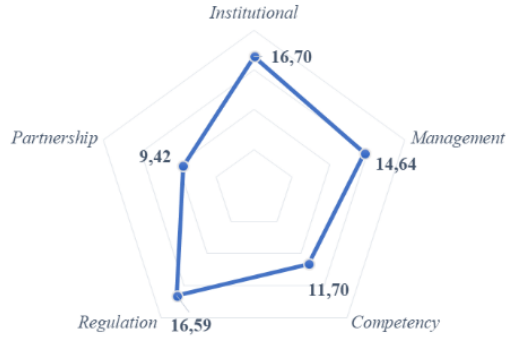

Source: Primary data (2019)

The institutional aspect is strongly influenced by poor governance standards and business legality that is not yet well established and certified. This reason makes financial institutions, including BPRS and Islamic Commercial Banks, reluctant to provide loans. Due to the large number of cases that put BPRS at high risk of loss due 
to the absence of collateral or guarantees in providing loans.

MFIs often charge interest on loans, with typically higher rates because credit is granted to high-risk borrowers with little or no collateral (Dehejia, Montgomery, \& Morduch, 2012). However, in contrast to other lending institutions, MFIs use different lending techniques (solidarity groups, rotating savings and credit associations, village banking, credit unions, individual lending, etc.) to achieve high recovery rates despite the high-risk borrowers.

Figure 4. The key performance index of an institutional problem

Key Performance Index of Institutional Problem

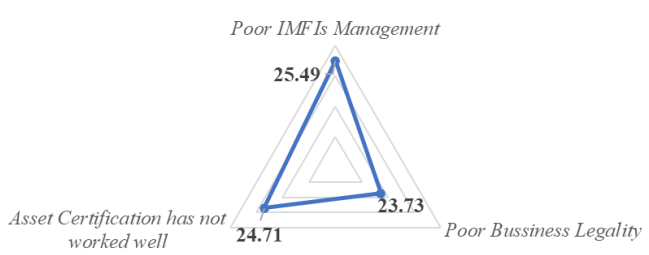

Source: Primary data (2019)

There is no provision and a good supervisory system on regulations related to the legal structure of IMFIs in Indonesia in terms of regulations. The various supervisory agencies that oversee IMFIs and the Bank have produced different deposit insurance systems and institutions. Extant literature showed that, unlike traditional banks, most MFIs do not have access to debt (Dorfleitner et al., 2016) and deposits (Galema et al., 2011). Indeed, only the very big and well-established MFIs have access to debt finance (Bogan, 2012).

IMFIs in Indonesia are under the Ministry of Cooperatives and SMEs and have different technical aspects in financial management. The financial supervision system does not have a good standard, such as banks supervised by the Ministry of Finance. Expertise, board activity, and ownership type are the main board characteristics that significantly determine MFI governance quality (Tchuigoua, 2015). Marr and Tubaro (2012) supported that building an enabling regulatory environment for funding partnerships could improve the capacity of MFIs to achieve its double bottom-line objective.

Figure 5. The key performance index of regulatory problem

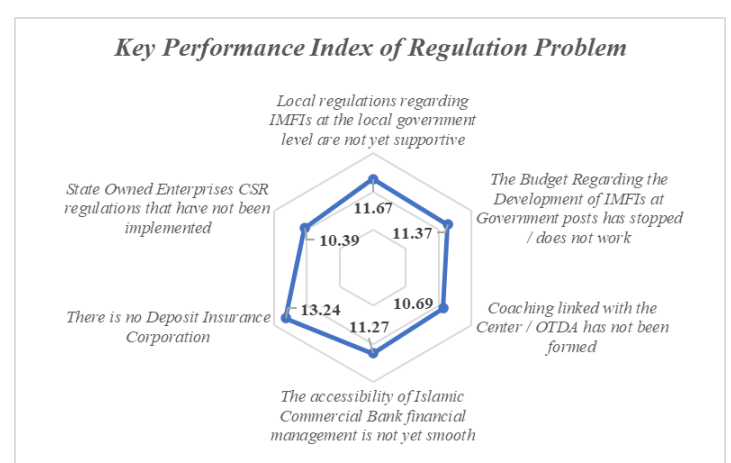

Source: Primary data (2019)

Regulatory aspects related to market segmentation need to be supported by precise targeting. In this case, an objective is an integrated approach related to services in the household sector. According to Matul \& Tsilikounas (2004), apart from market orientation towards households and micro, 
small and medium enterprises (MSMEs), it is necessary to establish programs that can reduce the financial vulnerability of households and micro, small and medium enterprises (MSMEs). Several examples of these improvements are related to increasing productivity through various policies by assisting in forming markets and economic clusters developed through product branding from a region. Economic factors, particularly GDP, have exhibited a positive relationship with productivity, implying that good economic performance can stimulate the productivity of MFIs (Mia \& Soltane, 2016). Another aspect related to management is human resources that are still not competitive with the management of public funds and the distribution of public fund portfolios. The level of education is still low, and the specification of human resources needed is not clear, which results in poor management of IMFIs funds.

Srinivasan (2010) noted that the training arrangements available in the microfinance sector were not uniformly good, and the competition among MFIs for human capital also meant that attrition levels were high. Besides, Srinivasan (2009) argued that human resources available to MFIs were scarce, which was a critical risk for the MFIs.

Incentive-based theories suggested that transferring the decision-making authority to agents who produce soft information is a way for lending organizations either to provide incentives for loan officer by rewarding his expertise (Aghion \& Tirole, 1997; Stein, 2002) or to reduce information acquisition costs (Sah \& Stiglitz, 1986). It may also hold for the microfinance sector, where loan approval and monitoring are delegated to the loan officer or the peers in joint liability contracts. Recent evidence suggested that decentralizing loan approval and using soft information in lending decisions increase MFIs outreach to the poor (TchakouteTchuigoua \& Soumaré, 2019). Hence, improving the capability of MFI employees or agents, in particular, is very important.

Figure 6. The key performance index of management problem

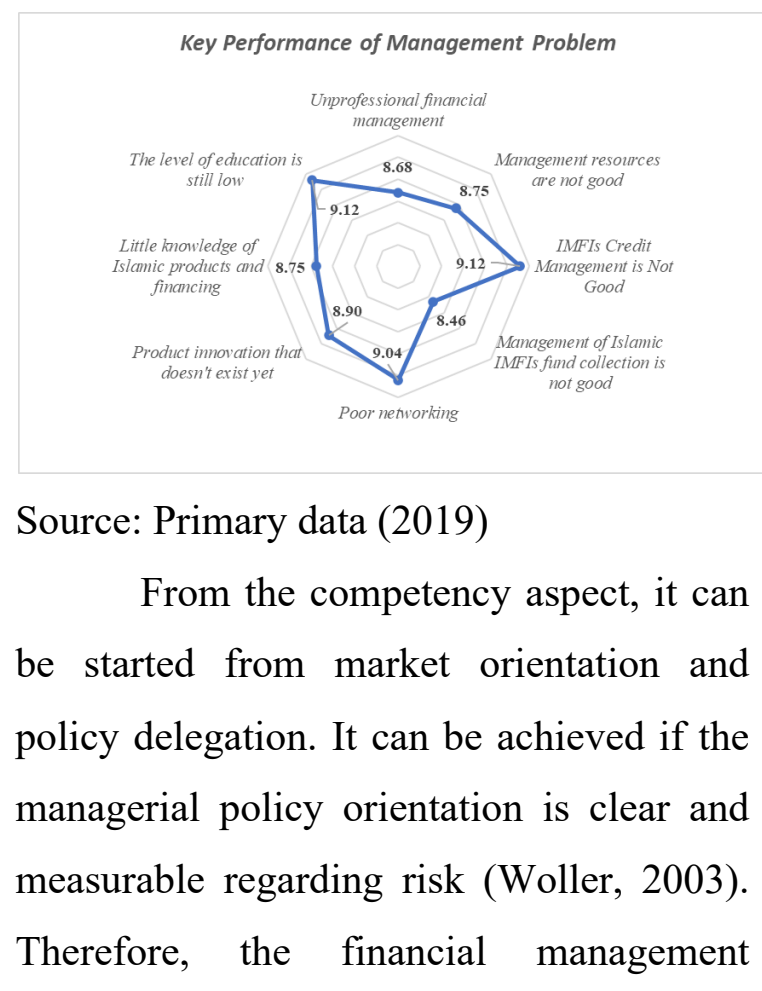


program and delegation of tasks are the starting points in developing financing. MFI-specific regulations need to be made simple and easy. It is under the typical MFI characteristics of ownership structure, governance, capital, funding, and risk (Chikalipah \& Makina, 2019).

Furthermore, Woller (2002) argues that management also needs to create programs that can reduce conflict and increase interaction between departments. Competence related to the market for micro, small and medium enterprises, which should be the IMFIs market in providing loans, is not going well. Thus, people prefer other banks to provide loans. Gutierrez-Goiria et al. (2016) found that the first analysis of the legal status, target market, scale, and age determines the efficiency of MFI using international data.

Besides, Islamic commercial banks that cooperate directly with the micro, small, and medium enterprise market without market segmentation make it difficult for IMFIs to compete in terms of funds and loan products.
Figure 7. The key performance index of competency problem

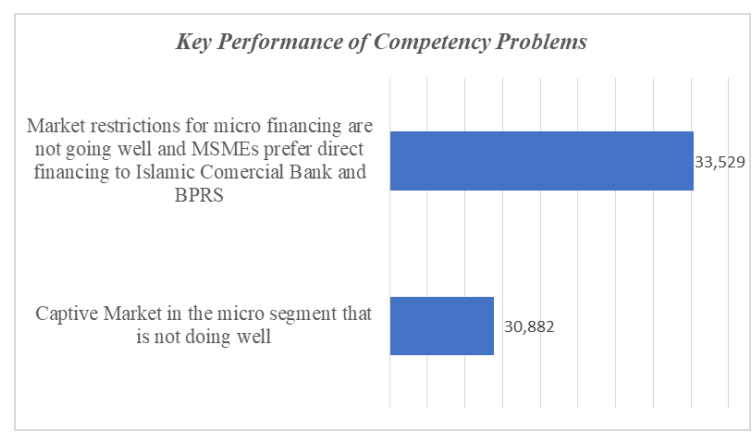

Source: Primary data (2019)

In the partnership aspect, no access can bring together IMFIs with financial institutions to provide capital and investment. Regarding the capital, trade-off theory posited an optimal capital that trades off costs, and benefits should enhance performance (Berger et al., 1995; Osborne et al., 2012). However, regulators' capital adequacy requirement means MFIs may not operate at the optimal capital, affecting performance. To reduce the risk of going below the capital adequacy ratio, MFIs may keep buffer capital.

Figure 8. The key performance index of partnership problem

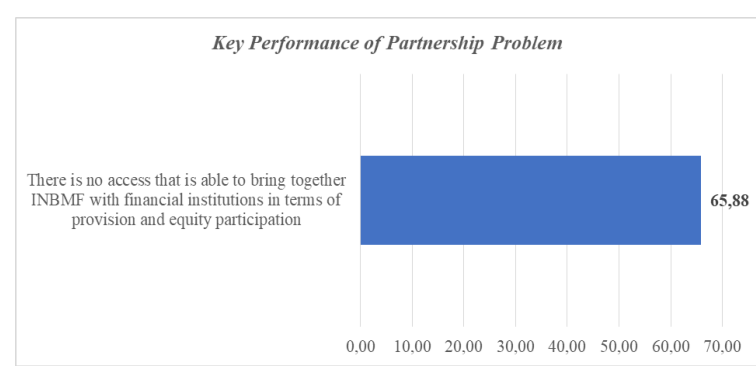

Source: Primary data (2019) 


\section{Key Performance Index of Solutions}

The regulatory aspect is a priority aspect $(21.43 \%)$ in increasing the efficiency of IMFIs financing, followed by solutions for management $(16.82 \%)$, institutional (15.86\%), competency (14.55\%), and partnership aspects (10.28\%).

Figure 9. Indicators of solution aspects

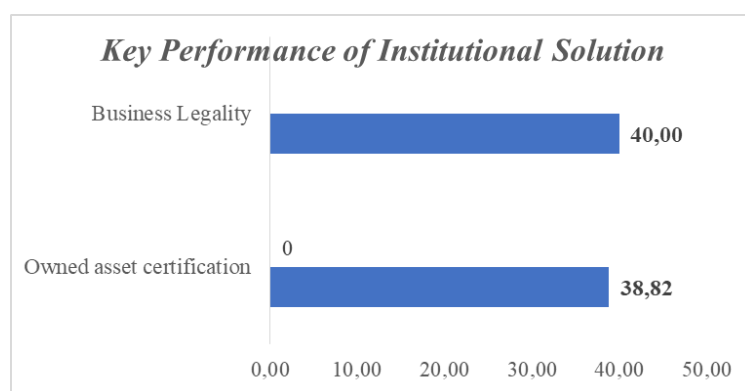

Source: Primary data (2019)

In regulation, improvement and solutions prioritized are the making of regulations related to IMFIs linkage financing budgeting from the central government to the local government (13.63\%) that can help IMFIs develop human resources, market and improve the quality of public financing. The law that regulates IMFIS to be registered in the Deposit Insurance Agency (DIG) is also crucial $(13.53 \%)$.

The legal framework creates an entity and empowers it to ensure the financial system's soundness (Dassler, 2006; Hahn, 1998; Gallardo, 2002). In their study of microfinance institutions and public policy, Hardy et al. (2003) contended that regulating the financial industry has beneficial implications for both financial systems and users of the sector. Several researchers (Seibel, 2006; The World Bank, 2004; Duggleby et al., 1992) argued that the primary reason for regulating and supervising financial activities, particularly traditional financial institutions, is protecting consumers.

Highlighting the importance of formal or informal rules, Ledgerwood and Gibson (2013) stated that the rules themselves and their enforcement "govern participation and behavior in financial market systems and strongly influence financial market outcomes." MFIs have to comply with formal rules set by local government or industry associations continuously related to their functioning and adhere to informal rules such as working with women or people of certain communities.

Figure 10. The key performance index of a regulatory solution

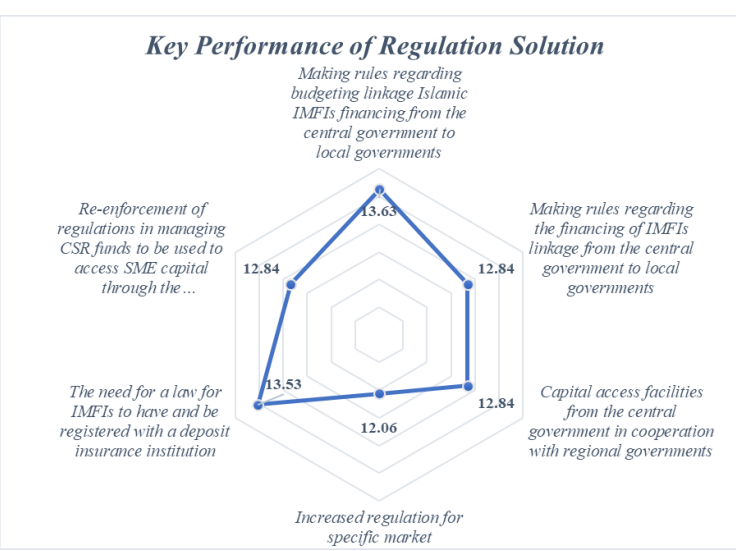

Source: Primary data (2019)

Management requires priority solutions for human resource training and development at 
IMFIs $(17.18 \%)$. The lack of education for existing human resources makes it difficult for IMFIs to develop product innovations from managerial and technological aspects. Organizational strategy, knowledge management, and innovation orientation will impact the ability of SMEs to develop and practice entrepreneurial management to seize market opportunities (Korpysa, 2020). Knowledge management capabilities can increase a business's capacity to innovate business models that have an impact on strengthening an enterprise in managing risk (Hock-Doepgen, Clauss, Kraus, \& Cheng, 2020). Besides, product innovation development supported by information technology $(17.06 \%)$ is also a fundamental solution for the development of IMFIs. Previous studies have considered the relationship between MFI and governance (Chakrabarty \& Bass, 2014; Mersland \& Strøm, 2009).

Figure 11. The key performance index of management solution

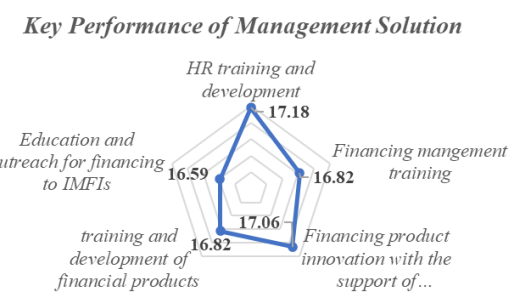

Source: Primary data (2019)

Business legality (40\%) and certification of assets owned (38.82\%) by IMFIs are required from the institutional aspect. This can help IMFIs have sound asset fundamentals in providing loans. Recent studies investigate how the institutional environment affects MFIs' lending by focusing on the role of the state (Ault \& Spicer, 2014) as well as culture and norms (Mair et al., 2012; Ault, 2016; Cobb et al., 2016; Zhao \& Lounsbury, 2016; Wry \& Zhao, 2018).

Figure 12. The key performance index of institutional solution

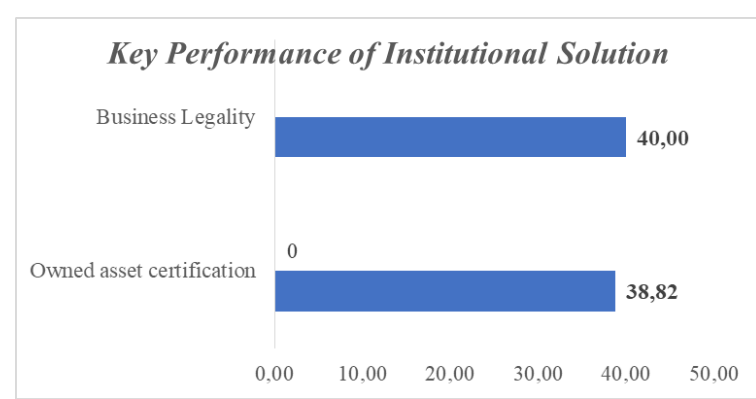

Source: Primary data (2019)

In terms of competency index solutions, competency training and development are needed in improving the quality of excellent customer service (21.18\%) and branding of IMFIs (19.71\%) to expand the IMF's market. The focus of organizational management on Integrated Quality Management is to improve performance (Eniola, Olorunleke, Akintimehin, Ojeka, \& Oyetunji, 2019). Market mapping and segmentation are the next priority solutions. 
Figure 4.11. The key performance index of competency solution

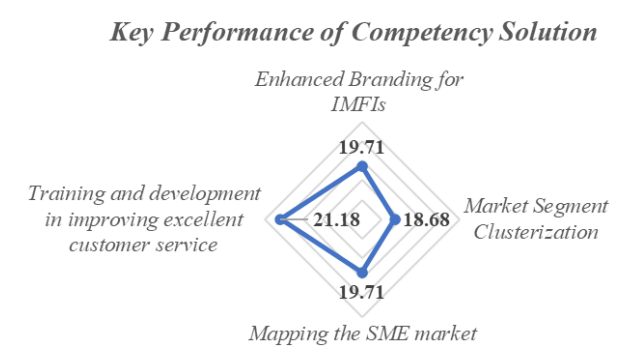

Source: Primary data (2019)

In terms of the partnership solution index, increased cooperation with IMFIs can be done through a joint venture scheme (18.53\%). Collaboration development through crowdfunding $(18.53 \%)$ is also a solution for further partnerships. Besides, increasing the distribution of financing to Muslim SME entrepreneurs (18.24\%) can also increase the market and strengthen funding. MFIs with an effective governance system tend to serve large numbers of customers (Tchakoute-Tchuigoua, 2017).

Figure 13. The key performance index of partnership solution

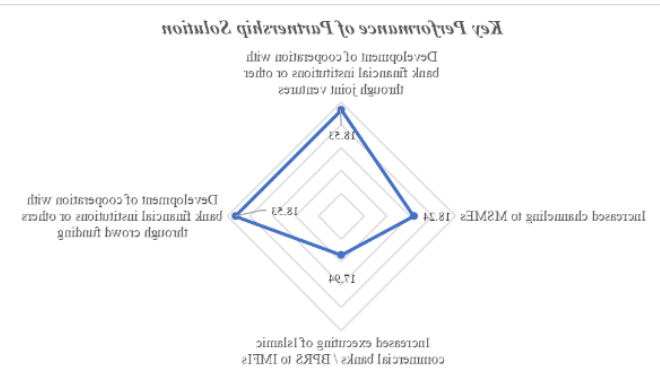

Source: Primary data (2019)

Interaction between institutions can help improve an institution's effectiveness, impacting the exchange of knowledge and information. Partnerships can provide cognitive benefits by sharing information about the operational process. Institutional interactions that are maintained can increase the value of resources owned; therefore, it needs to be carried out strategically according to institutions' needs (Sanderink, \& Nasiritousi, 2020).

\section{Conclusion}

The research results show that Islamic non-banking microfinance institutions (MFIs) existing priority problem is channeling funds to non-bank Islamic financial institutions because of their internal management problems. Internal management problem related to government is the highest priority. The other problems are legalization, human resource management, expertise, and professionalism in managing loan funds.

The external problem is mostly caused by government regulation. A small number of non-banking MFIs also has no relationship with The Deposit Insurance Agency (DAG). It causes the provision of funds to non-bank financial institutions still considered to have a high risk. The partnership aspect can be learned from the difficulty of getting a market for Islamic financing products. It is due to market confidence. In this case, the public and 
micro, small, and medium enterprises (MSMEs) have more confidence in Islamic general banking (BUS - Bank Umum Syariah) and Islamic Rural Bank (BPRS Bank Perkreditan Rakyat Syariah) with better and innovative institutional financing systems as well as financing products and other financing products.

Finally, several priority solutions are needed relating to strengthening governance and institutional standards. The internal solution is to increase human resource management's capacity and expertise to make it more professional, strengthen the organizational status and legal entities of Islamic microfinance institutions. Meanwhile, based on the external perspective, it is necessary to regulate the rules for limiting the value of financing in Islamic general Bank (BUS - Bank Umum Syariah), Islamic People's Rural Bank (BPRS - Bank Perkreditan Rakyat Syariah), and Islamic non-banking MFIs to create market segment allocations.

Future research can extend these results of the study, incorporate other important criteria and factors, and consider the interdependent relations between multiple key factors to improve further the key factors affecting non-banking MFIs performance. Future research could also investigate whether there are differences between the key factors that financial providers with different levels of resources consider when providing financing services.

\section{Reference}

Abbas, K., \& Shirazi, N. (2015). The key players' perception on the role of Islamic microfinance in poverty alleviation: The case of Pakistan. Journal of Islamic Accounting and Business Research, 6(2), 244-267.

Agarwal, A., Shankar, R., \& Tiwarib, M.K. (2006). Modeling the metrics of lean, agile and leagile supply chain: An ANP-based approach. European Journal of Operational Research, 173(1), 211-225.

Aghion, P., \& Tirole, J. (1997). Formal and real authority in organizations. Journal of Political Economy, 105, 129.

Ahmad, A.U.F., \& Ahmad, A.B.R. (2009). Islamic microfinance: the evidence from Australia. Humanomics, 25(3), 217-235

Antonio, M.S. (2008). "Islamic microfinance initiatives to enhance small and medium-sized enterprises", in Greg, F. and Sally, W. (Eds), Expressing Islam: Religious Life and Politics in Indonesia, ISEAS Publishing, available at: http://ehis.ebscohost.com/eds/pdfvie wer/pdfviewer?sid9e3bc053-50894575-9bb7-

fcc2b6ee43a2\%40sessionmgr4002\&v id2\&hid4113 (Accessed 10 August 2020), 251-266.

Armstrong, K., Ahsan, M., \& Sundaramurthy, C. (2018). Microfinance ecosystem: How connectors, interactors, and institutionalizers co-create value. Business Horizons, 61(1), 147-155. 
Tasya Aspiranti dkk; The Role Of Government Policy In Developing The Islamic

https://doi.org/10.1016/j.bushor.2017. $\underline{09.014}$.

Ault, J.K. (2016). An institutional perspective on the social outcome of entrepreneurship: commercial microfinance and inclusive markets. Journal of International Business Studies, 47 (8), 951-967.

Ault, J.K., \& Spicer, A. (2014). The institutional context of poverty: state fragility as a predictor of crossnational variation in commercial microfinance lending. Strategic Management Journal, 35 (12), 1818 1838.

Bashar, T., \& Rashid, S. (2012). Urban microfinance and urban poverty in Bangladesh. Journal of the Asia Pacific Economy, 17(1), 151-170. https://doi.org/10.1080/13547860.201 2.640019.

Berger, A.N., Kashyap, A.K., \& Scalise, J.A. (1995). The transformation of the U.S. Banking industry: what a long strange trip it's been. In: Brookings Papers on Economic Activity., pp. 2.

Bogan, V.L. (2012). Capital structure and sustainability: an empirical study of microfinance institutions. The Review of Economics and Statistics, 94 (4), 1045-1058.

Chakrabarty, S., \& Bass, A.E. (2014). Corporate governance in microfinance institutions: board composition and the ability to face institutional voids. Corporate Governance An International Review, 22 (5), 367386.

Chen, H.H., Kang, H., Xing, X., Lee, A.H.I., \& Tong, Y. (2008). Developing new products with knowledge management methods and process development management in a network. Computers in Industry, 59, 242-53.

Chikalipah, S. (2018). Credit risk in microfinance industry: Evidence from sub-Saharan Africa. Review of Development Finance, 8(1), 38-48. https://doi.org/10.1016/j.rdf.2018.05. $\underline{004}$.

Cobb, J.A., Wry, T., \& Zhao, E.Y. (2016). Funding financial inclusion: institutional logics and the contextual contingency of funding for microfinance organizations. Academy of Management Journal, 59 (6), 21032131.

Dassler, T. (2006), "Combining theories of regulation - proposing a framework for analysing regulatory systems worldwide", Utilities Policy, Vol. 14 No. 1, pp. 31-43.

De Fontenay, C., \& Wood, C. (2018). Is microfinance raising village income? The issue of excess entry. Economics Letters, 165, 17-20. https://doi.org/10.1016/j.econlet.2018 .01 .016 .

Dehejia, R., Montgomery, H., \& Morduch, J. (2012). Do interest rates matter? Credit demand in the Dhaka slums. Journal of Development Economics, 97(2), 437-449.

Dorfleitner, G., Röhe, M., \& Renier, N. (2016). The access of microfinance institutions to debt capital: an empirical investigation of microfinance investment vehicles. Journal of Sustainable Finance \& Investment, $65,1-15$.

Duggleby, T.J., Aryeetey, E., \& Steel, W. (1992), "Formal and informal finance for small enterprises in Ghana", Industry Development Division, Industry and Energy Department, 
Office of Sponsored Programs, Washington, DC.

Eversole, R. (2003). Help, Risk and Deceit: Microentrepreneurs Talk About Microfinance. Journal International Development, 179-188.

Feibert, D.C., Sørup, C.M., \& Jacobsen, P. (2016). Using the Analytic Network Process(ANP) to assess the distribution of pharmaceuticals in hospitals - a comparative case study of a Danish and American hospital, 5th World Conf Prod Oper Manag Join P\&OM Forces Worldw Present Futur Oper Manag;. p. 10.

Galema, R., Lensink, R., \& Spierdijk, L. (2011). International diversification and microfinance. Journal of International Money and Finance, 30 (3), 507-515.

Gallardo, J. (2002), "A framework for regulating microfinance institutions, the experience in Ghana and the Philippines", Policy Research Working Paper 2755, The World Bank, Washington, DC.

Gutierrez-Goiria, J., L. San-Jose, \& J. LuisRetolaza. (2016). 'Social Efficiency in Microfinance Institutions: Identifying How to Improve It'. Journal of International Development, 29 (2): 259-280.

Hahn, R.W. (1998), “Government analysis of the benefits and costs of regulation", Journal of Economic Perspectives, Vol. 12 No. 4, pp. 201210.

Hardy, D.C., Holden, P., \& Prokopenko, V. (2003), "Microfinance institutions and public policy", Journal of Economic Policy Reform, Vol. 6 No. 3 pp. 147158.

Hassan, A. (2015). Financial inclusion of the poor: from microcredit to Islamic microfinancial services. Humanomics, 31(3), 354-371.

Hassan, S., Abdul Rahman, R., Abu Bakar, N., Mohd, R., \& Muhammad, A.D. (2013). Designing islamic microfinance products for islamic banks in Malaysia. Middle-East Journal of Scientific Research, 17(3), 359-366.

Hassan, A., \& Saleem, S. (2017). An Islamic microfinance business model in Bangladesh: Its role in alleviation of poverty and socio-economic wellbeing of women. Humanomics, 33 (1), $15-37$

Hermes, N. (2014). Does microfinance affect income inequality?. Applied Economics, 46 (9), 1021-1034. https://doi.org/10.1080/00036846.201 3.864039 .

Hock-Doepgen, M., Clauss, T., Kraus, S., \& Cheng, C. F. (2020). Knowledge management capabilities and organizational risk-taking for business model innovation in SMEs. Journal of Business Research.

Juwaini, A., Rambe, M., Mintarti, N., \& Febrianto, R. (2010). BMT (Baitulmaal wa Tamwil) Islamic microfinance services for the poor, paper presented at ISO/COPOLCO Workshop, Bali, May, available at: www.scribd.com/document/1860132 86/BMT-Islamic-MicrofinancialServices-forthe-Poor (accessed 07 September 2020).

Karim, N., Tarazi, M., \& Reille, X. (2008). Islamic Microfinance: an emerging market niche, Focus Note, 49, CGAP, August.

Kheybari, S., Rezaie, F.M., \& Farazmand, H. (2020). Analytic network process: An overview of applications. Applied 
Tasya Aspiranti dkk; The Role Of Government Policy In Developing The Islamic

Mathematics and Computation, 367, 124780 .

Korpysa, J. (2020). Entrepreneurial management of SMEs. Procedia Computer Science, 176, 3466-3475

Kikkawa, K., \& Xing, Y. (2014). Financial inclusion in Indonesia: a poverty alleviation strategy, Financial Inclusion in Asia Country Surveys, Asian Development Bank Institute, 4561.

Ledgerwood, J., \& Gibson, A. (2013), The Evolving Financial Landscape. In the New Micro fi nance Handbook: A Financial Market System Perspective, World Bank Publications, Washington, DC, pp. 15-48.

Machado, V.H., Barroso, A.P., \& Machado, V.C. (2014). An Analytic Network Process model to support decision making in a pharmaceutical supply chain. In: 2013 IEEE International Conference on Industrial Engineering and Engineering Management. 16121616 New York. doi:https://doi.org/10.1109/IEEM.201 3.6962682 .

Mair, J., Martí, I., \& Ventresca, M.J. (2012). Building inclusive markets in rural Bangladesh: how intermediaries work institutional voids. Academy of Management Journal, 55 (4), 819850.

Marr, A., \& Tubaro, P. (2012), "Global financial partnerships in microfinance: India, Peru and Tanzania", Revista Iberoamericana de Estudios de Desarrollo $=$ Iberoamerican. Journal of Development Studies, Vol. 1 No. 1, pp. 28-57.

Mersland, R., \& Strøm, R.Ø. (2009). Performance and governance in microfinance institutions. Journal of
Banking and Finance, 33 (4), 662669.

Maulana, H., Razak, D.A., \& Adeyemi, A.A. (2018). Factors influencing behaviour to participate in Islamic microfinance. International Journal of Islamic and Middle Eastern Finance and Management, 11 (1), 109-130.

Matul, M., \& Tsilikounas, C. (2004). Role Of Microfinance In The Household Reconstruction Process In Bosnia and Herzegovina. Journal of International Development, 429-466.

Mia, M. A., \& Soltane, B. I. B. (2016). Productivity and its determinants in microfinance institutions (MFIs): Evidence from South Asian countries. Economic Analysis and Policy, 51, 32-45.

Obaidullah, M. (2015). Enhancing food security with Islamic microfinance: insights from some recent experiments. Agricultural Finance Review, 75 (2), 142-168.

Financial Services Authority. (2019). Islamic Banking Report. Jakarta.

OJK. (2020). Statistik Perbankan Syariah November 2020.

Osborne, M., Fuertes, A.-M., \& Milne, A. (2012). Capital and Profitability in Banking: Evidence from US Banks. Cass Business School Working Paper.

Rusydiana, A. S., \& Devi, A. (2013). Challenges in Developing Baitul Maal wat Tamwiil (BMT) in Indonesia using Analytic Network Process (ANP). Business and Management Quarterly Review (BMQR), 4(1), 5162.

Saaty, T.L. (1980). The Analytic Hierarchy Process. McGraw-Hill, New York. 
Saaty, T.L. (2006). Decision Making With The Analytic Network Process. Boston: Springer.

Saaty, T.L., \& Vargas, L.G. (2013). The Analytic Network Process. Decision Making Analytic Network Process. 195, $1-40$.

https://doi.org/10.1007/978-1-46147279-7 1.

Sah, R., \& Stiglitz, J. (1986). The architecture of economic systems: Hierarchies andpolyarchies. American Economic Review, 76, 716-727.

Sanderink, L., \& Nasiritousi, N. (2020). How institutional interactions can strengthen effectiveness: The case of multi-stakeholder partnerships for renewable energy. Energy Policy, 141, 111447.

Sarkis, J., \& Sundarraj, R. (2006). Evaluation of enterprise information technologies: a decision model for high-level consideration of strategic and operational issues, IEEE Trans. Syst. Man Cybernet. C (Applic. Rev.) 36, 260-273.

Sarkis, J., \& Talluri, A.G. (2007). A strategic model for agile virtual enterprise partner selection. International Journal of Operations \& Production Management, 27, 12131234

Segrado, C. (2005). Islamic Microfinance and Socially Responsible Investments, A Case Study, University of Torino, available at: http://segrado.com/chiara/islamic_mi crofinance.

Seibel, H.D. (2006), "From informal microfinance to linkage banking: putting theory into practice, and practice into theory", European Dialogue, No 36, pp. 49-60.
Sipahi, S., \& Timor, M. (2010). The analytic hierarchy process and analytic network process: an overview of applications. Management Decision, 48 (5), 775-808.

Srinivasan, N. (2009), "Microfinance India: state of the sector report 2008", SAGE Publications India.

Stein, J. C. (2002). Information production and capital allocation: Decentralized versushierarchical firms. Journal of Finance, 57(5), 1891-1921.

Srinivasan, N. (2010), "Microfinance India: state of the sector report 2009", SAGE Publications India.

Sudarso, H. (2003). Bank Lembaga Keuangan Syariah: Deskripsi dan Ilustrasi. Yogyakarta: Ekonisia.

Tavanti, M. (2013). Before Microfinance: The Social Value of Microsavings in Vincentian Poverty Reduction. Journal of Business Ethics, 112(4), 697-706.

https://doi.org/10.1007/s10551-0121566-1

Tchakoute-Tchuigoua, H. (2017). Which types of microfinance institutions decentralize the loan approval process? Quarterly Review of Economics and Finance. https://doi. org/10.1016/j.qref.2017.07.002.

Tchakoute-Tchuigoua, H., \& Soumaré, I. (2019). The effect of loan approval decentralization on microfinance institutions' outreach and loan portfolio quality. Journal of Business Research, 94, 1-17.

The World Bank (2004), Doing Business in (2004), Understanding Regulations, World Bank and Oxford University Press, Washington, London.

Undang-Undang Nomor 21 Tahun 2008 Tentang Perbankan Syariah. 
Ulina, S., \& Majid, M.S.A. (2020). A Comparative Analysis Of Determinants Of Islamic And Conventional Banking Performances In Indonesia. Amwaluna: Jurnal Ekonomi dan Keuangan Syariah, 4 (2), 176-192.

Woller, G. (2002). From Market Failure to Marketing Market Orientation As The Key to Deep Outreach in Microfinance. Journal of International Development, 305-324.

Wry, T., \& Zhao, E.Y. (2018). Taking tradeoffs seriously: examining the contextually contingent relationship between social outreach intensity and financial sustainability in global microfinance. Organization Science, 29 (3), 507-528.

Yellepeddi, S., Liles, D.H., \& Rajagopalan, S. (2006). An Analytical Network Process (ANP) approach for the development of a reverse supply chain performance index in consumer electronics industry. (004-0069).

Zhao, E.Y., \& Lounsbury, M. (2016). An institutional logics approach to social entrepreneurship: market logic, religious diversity, and resource acquisition by microfinance organizations. Journal of Business Venturing, 31 (6), 643-662. 